\title{
CHARACTERIZATION OF TRIBOLOGICAL BEHAVIOR OF CHROMIUM AND ZINC COATINGS ELECTRODEPOSITED ON A STEEL SUBSTRATE
}

\author{
S. RHAIEM ${ }^{1,2}$, F. NASRI $^{1}$, M. KHARRAT ${ }^{1,2}$, M. DAMMAK $^{1,2}$ \\ ${ }^{1}$ Ecole Nationale d'Ingénieurs de Sfax, Tunisia; \\ ${ }^{2}$ Institut Préparatoire aux Etudes d'Ingénieurs de Sfax, Tunisia
}

Three coatings of decorative chromium, hard chromium and zinc, electrolytically deposited on the C45 steel substrate, are considered in this study. Experimental characterization of the tribological response of the substrate and different coatings against spherical $100 \mathrm{Cr} 6$ counterbody is developed with a linear reciprocating tribometer. The results show that the three coatings have similar values for the stabilized coefficient of friction which remains substantially higher than the value of the friction coefficient for the substrate. The decorative chromium coating has the lowest wear resistance. A better wear resistance is obtained with the zinc coating. The first place in terms of wear resistance is occupied by the hard chromium coating and the uncoated substrate which have similar resistance.

Keywords: coatings; substrate; electrolytic; chromium; zinc; friction; wear.

The term "surface treatments" means all operations: mechanical, chemical, electrochemical or physical which affect the appearance or structure of the material surface to suit the operating conditions data. Surface treatments are variable and can improve the optical properties or appearance, resistance to wet or dry corrosion, thermal or electrical conductivity, response to friction, wear resistance. Treatments such as chromium, zinc, aluminum coatings are now widely used in many industrial and domestic sectors. Treated surfaces may be the seat of the phenomena of friction and wear in case they are in contact with a rigid counterbody. This may cause local fracture of the coating and therefore the activation of the corrosion phenomenon. The response of tribological coatings of chromium electrodeposited on a mild steel substrate was studied in [1]. The authors showed that the coatings have better wear resistance than the uncoated substrate. The wear behavior of electrolytic hard chromium (EHC) and arc PVD CrN coatings under lubrication was investigated in [2] and the researchers concluded that the friction coefficient of $\mathrm{EHC}$ is higher than the friction coefficient of $\mathrm{CrN}$ but the wear resistance of $\mathrm{EHC}$ is lower than that of $\mathrm{CrN}$. The tribological behavior of $\mathrm{EHC}$ coatings sliding against ceramic and steel counterparts was investigated in [3]. They showed that in the case of steel ball as a counterbody the wear mechanism of EHC can be divided into three stages: adhesion and formation of debris; formation of abrasive particles and abrasive wear and dominance of abrasive wear. Other researchers have investigated the mechanical and tribological properties of EHC and HVOF (High Velocity Oxy-Fuel) to prove that EHC cannot form a smooth tribofilm [4]. Under high contact pressures this film is easily fractured and partly removed. Therefore EHC coatings undergo higher mass losses and develop higher friction coefficient than the HVOFsprayed coatings in the same conditions. Some other researchers have studied the friction response of electrodeposited coatings of zinc and zinc with ash deposited on the mild steel substrate [5]. They showed that the zinc coating has a friction coefficient greater than that of the steel substrate, while the zinc coating with ash has a friction coefficient lower than that of the steel substrate. The authors of another paper have

Corresponding author: M. KHARRAT, e-mail: mohamed.kharrat@ipeis.rnu.tn 
studied the sliding wear behavior of Zinc and Zn-Co alloy electrodeposits and they made a conclusion that the friction coefficient of zinc is higher than the friction coefficient of $\mathrm{Zn}-0.6 \% \mathrm{Co}$ and $\mathrm{Zn}-4 \% \mathrm{Co}$, but the wear rate is lower for the zinc than for the alloys [6]. They also concluded that the wear mechanism was found to have plastic deformation and shearing of the coatings surface layers. Some other researches have studied the response to friction and wear of pure zinc and zinc-iron alloys electrolytically deposited [7]. They conclude that the coefficient of friction of pure zinc against a stainless steel ball of $5.5 \mathrm{~mm}$ in diameter and $900 \mathrm{H}_{v}$ is higher than that of the other zinc-iron alloys and pure zinc has the highest volume wear rate.

The objective of this work is to characterize the tribological response of three electrodeposited coatings: chromium decorative, hard chromium and zinc deposited on the steel $\mathrm{C} 45$ substrate. Cyclical friction tests against a rigid counterbody are developed on the three coatings and the results in terms of response friction and wear are compared and analyzed.

Materials and methods. Cylindrical substrates of $20 \mathrm{~mm}$ in diameter and $15 \mathrm{~mm}$ in height were cut from the carbon steel C45 bar. Mechanical polishing with sand paper of size 200, 400 was applied on the two flat surfaces of each substrate. The arithmetic average roughness of the substrate after polishing was measured with a profilometer "SJ-210" and the average value obtained was $R_{a}=1.1 \mu \mathrm{m}$. Decorative chromium and zinc plating was carried out in industrial companies specialized in this field, while the hard chromium plating was done in our laboratory. For each of the three types of coatings, thicknesses were measured by the eddy current technique, using a modular type Elcometer 355 Top. Table 1 gives the mean values of the measured thicknesses. In the same table the arithmetic mean roughness of different coatings is given. A microdurometer type "402 MVD" was used for characterizing the hardness of the substrate and the deposited coatings. The tests were developed using a diamond indenter in the shape of a square pyramid with an angle between edges $\alpha^{\prime}=148^{\circ}$. The load $P$ applied to the substrate is $1000 \mathrm{~g}$, to the hard chromium coating it is $100 \mathrm{~g}$ and to the decorative chromium and zinc coatings $-50 \mathrm{~g}$. For each test, the hardness $H_{v}$ and penetration $h$ of the indenter are calculated from the measured value of the diagonal $D$ footprint using the following expressions [8]:

$$
h=\frac{D}{2 \operatorname{tg}\left(\alpha^{\prime} / 2\right)} H_{v}=1,854 \frac{P}{D^{2}} .
$$

Table 1. Thickness and roughness of the coatings layers

\begin{tabular}{|c|c|c|c|}
\hline & $\begin{array}{c}\text { Decorative } \\
\text { chromium }\end{array}$ & $\begin{array}{c}\text { Hard } \\
\text { chromium }\end{array}$ & Zinc \\
\hline Thickness, $\mu \mathrm{m}$ & 23 & 24 & 11.5 \\
\hline$R_{a}, \mu \mathrm{m}$ & 0.9 & 1.4 & 1.1 \\
\hline
\end{tabular}

To characterize the tribological response of the coatings and substrate in this study, a linear alternating motion tribometer was used. This device allowed us to put the coating surface in contact with a 100Cr6 ball counterbody (40 $\mathrm{mm}$ in diameter) under an imposed normal force $F_{n}$. The coated substrate was then driven in alternating translational movement produced by the combination of a gear motor and a rod/crank system. A force sensor was used to measure the tangential force and a data acquisition system allowed the continuous recording of this effort. The tests were developed for a frequency of $1 \mathrm{~Hz}$, an amplitude of $\pm 7.5 \mathrm{~mm}$, maximum number of cycles of 800 and two values of the imposed normal force: $57 \mathrm{~N}$ and $81.2 \mathrm{~N}$. For each coating and each value of the normal force, minimum three tests were performed.

At the end of each friction test, the data processing could be traced back to changes in the friction coefficient evolution with the number of cycles. For the analysis of 
the damage the wear on the coating surface was inspected under an optical microscope. An optical microscope type "LEICA DMILM" equipped with a digital camera and allowing a maximum magnification of 500 was used. Topographical signs of wear on different coatings were also established using the profilometer "SJ-210". These results were used to trace the maximum penetration of wear.

Results and discussion. Micro hardness. The micro hardness test results are presented in Table 2. It appears at first for each of the three coatings that the penetration $h$ is significantly less than the thickness. The measured value of hardness characterizes essentially the coating and not the substrate. It also appears that the hardness of hard chromium is much higher than that of the substrate. However, the decorative chrome plating and zinc represent the hardness which remains below the hardness of the substrate.

Table 2. Micro hardness of substrate and coatings

\begin{tabular}{|c|c|c|c|c|}
\hline & Substrate & Decorative chromium & Hard chromium & Zinc \\
\hline Penetration $h, \mathrm{~mm}$ & & 3.37 & 2.62 & 5.4 \\
\hline$H_{v}$ & 215.5 & 150 & 682 & 60 \\
\hline
\end{tabular}

Response to friction. Fig. 1 shows typical curves on the evolution of the friction coefficient $\mu$ with the number of cycles in the case of the uncoated substrate and for the two considered normal forces. It appears that the friction coefficient shows a rapid growth with the number of cycles at the beginning of the test to stabilize after 200 cycles. For both values considered of imposed normal force Fig. 2 shows the coefficient of friction after 800 cycles for the uncoated substrate and for different coatings. The uncoated substrate has the lowest coefficient of friction. It is of the order of 0.65 . This value remains unchanged for both considered normal

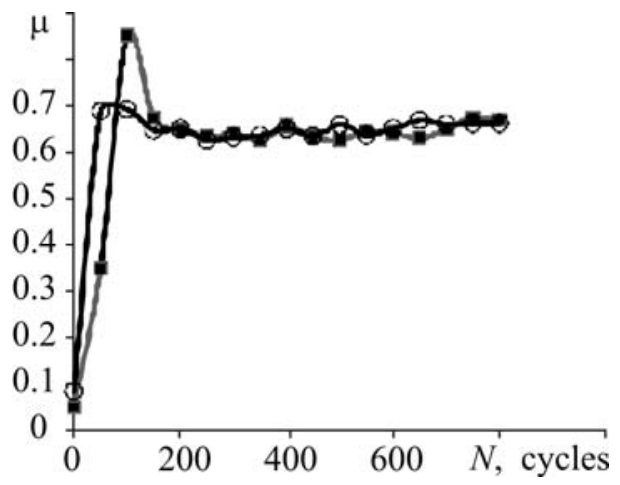

Fig. 1. Typical curves of friction coefficient vs. number of cycles in the case of uncoated substrate and for two considered normal forces values: $-57 \mathrm{~N} ; \mathrm{O}-81.2 \mathrm{~N}$.

forces. It also appears that the three coatings present similar values of the friction coefficient. These values show a significant increase with the applied normal force (approximately 0.7 to 0.9 ).

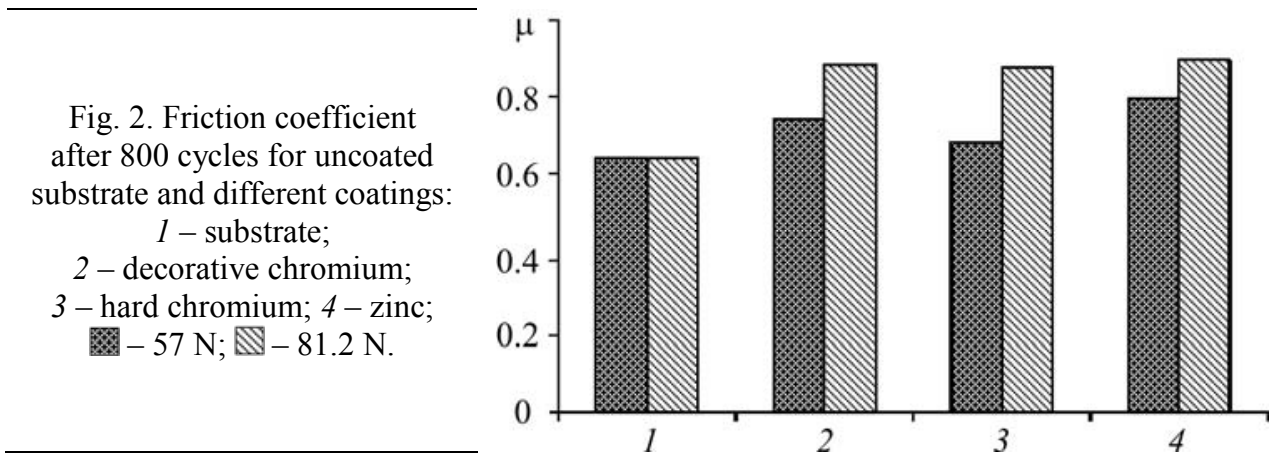

Response to wear. Microscopic observation of the wear tracks on the uncoated substrate and different coatings shows that several different wear mechanisms are activated. For the uncoated substrate intense plowing is located on the edges of the track while the inside of the track there is the seat of plastic deformation with production of 
oxide layers. The same phenomena were observed for decorative chromium coatings (Fig. $3 a, b$ ) and zinc. However, the morphology of the domed surface of the hard chrome coating leads to a particular wear mechanism. For this coating, the domes are clipped while wear debris is trapped in the valleys (Fig. $3 c, d$ ).
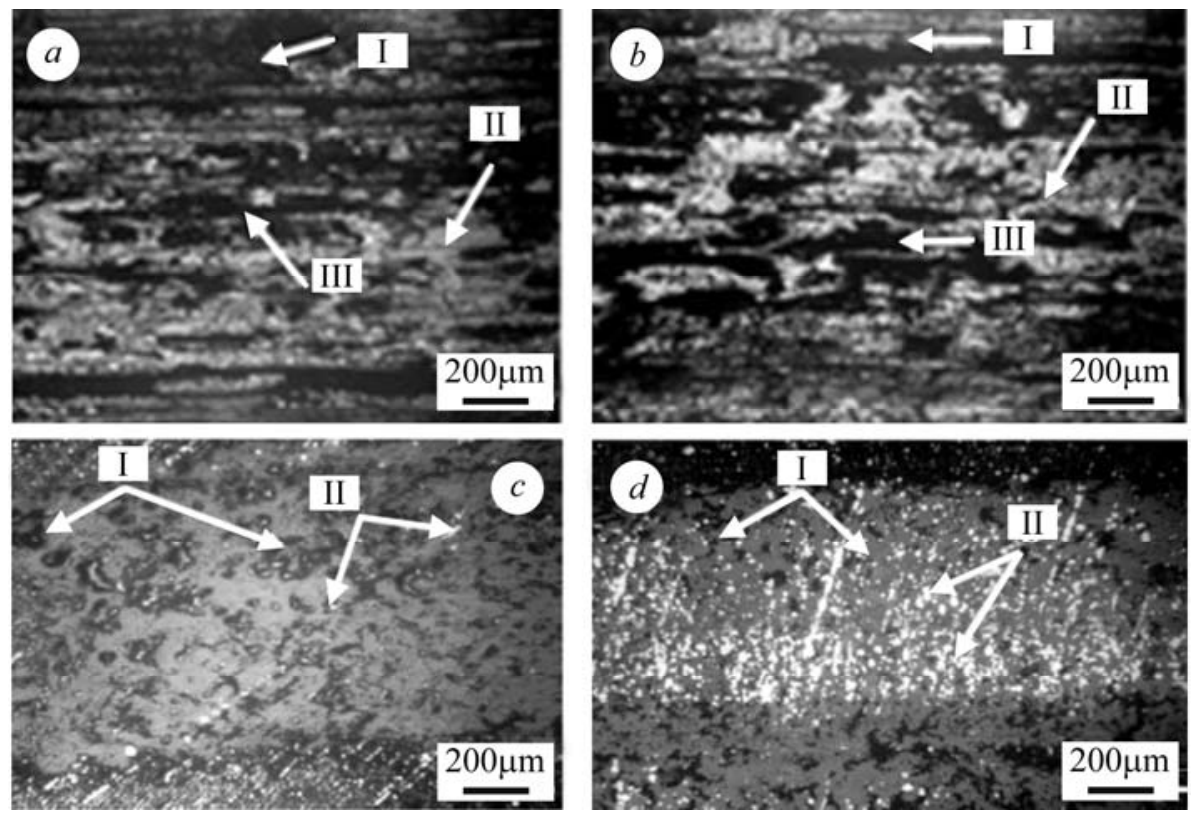

Fig. 3. Optical micrographs of the wear track on the coating of decorative

( $a, b$ : I - plowing; II - plastic deformation; III - oxide layers) and hard chromium (c, $d$ : I - worn domes; II - wear particles): $a, c-F_{n}=57 \mathrm{~N} ; b, d-81.2 \mathrm{~N}$.
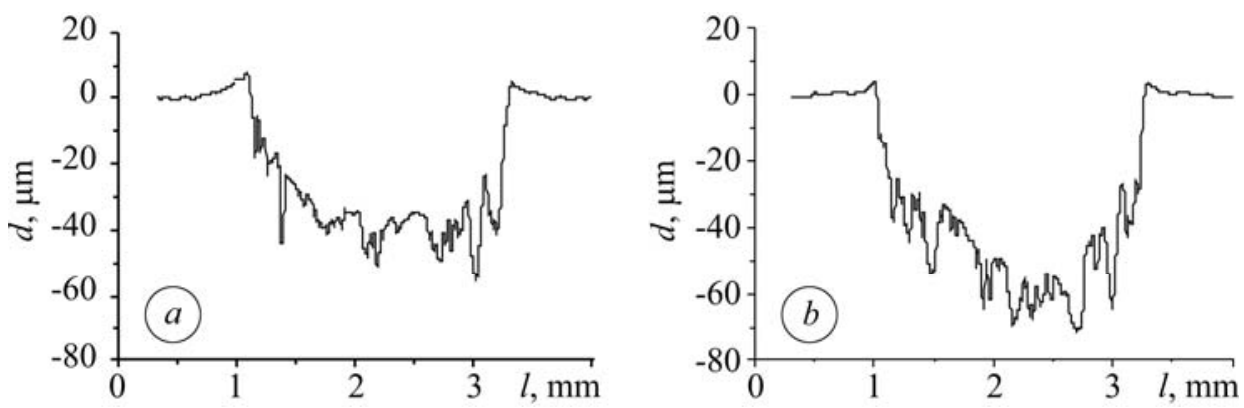

Fig. 4. Profile of the wear track on the coating of decorative chromium: $a-F_{n}=57 \mathrm{~N} ; b-81.2 \mathrm{~N}$.

To compare the severity of wear between coatings and uncoated substrate we evaluated the maximum penetration of wear (after 800 cycles). This penetration was measured on topographical signs of wear. Fig. 4 shows the example of topographic traces of wear (depth $d$ and width $l$ ) on the decorative chrome plating for both considered values of imposed normal force. Fig. 5 synthesizes the determined values of the maximum depth $d_{\max }$ of wear track to the uncoated substrate and different coatings. It follows that the measured penetration of wear is similar for the uncoated substrate and the coating of hard chromium. These latter surfaces have the lowest penetration of wear and therefore the best wear resistance. The second place in terms of wear resistance is occupied by the zinc coating while the coating of decorative chromium has the lowest wear resistance. Moreover, the experience shows that for all surfaces investigated in this study the increase in the imposed normal force leads to the increase in the penetration of wear. 


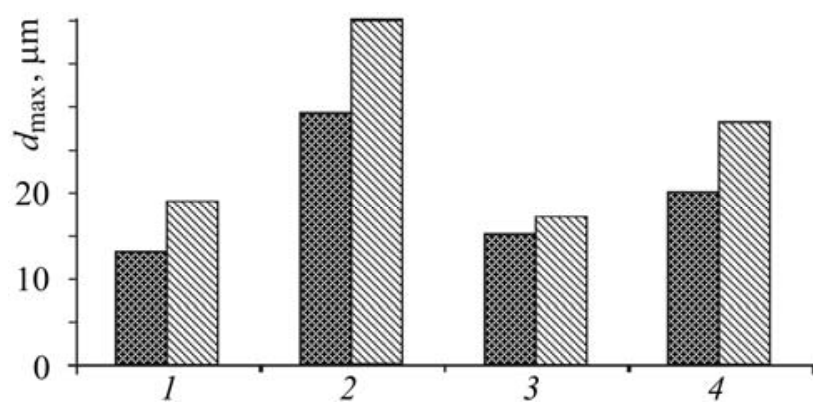

Fig. 5. Maximum depth of wear track to the uncoated substrate and different coatings: 1 - substrate; 2 - decorative chromium; 3 - hard chromium; 4 - zinc; $-57 \mathrm{~N} ; \mathbb{\mathbb { N }}-81.2 \mathrm{~N}$.

\section{CONCLUSION}

The experimental stu-

dy developed in this work shows that the uncoated substrate presents the lowest value of the friction coefficient. The hard chromium coating and the uncoated substrate are comparable in terms of wear resistance while the lowest wear resistance is obtained with the coating of decorative chromium. It was also shown that increasing the imposed normal force, even if it was not large enough, caused a significant increase in the maximum wear track depth. The main wear mechanism of zinc and decorative chromium coatings was noted to be severe shearing of the surface layers of the coating mainly due to plowing action of the steel ball. But for the hard chromium the wear mechanism seems to be abrasive, the domes are clipped and debris is trapped in the valleys.

PЕЗЮМЕ. Досліджено трибологічну поведінку трьох видів електролітичних покривів: декоративного хрому, твердого хрому та цинку, сформованих на підкладці зі сталі C45. Використано трибометр за умов зворотно-поступального руху контртіла. Виявлено, що для всіх покривів значення стабілізованого коефіцієнта тертя однакові, однак, істотно вищі, ніж для підкладки. Покрив з декоративного хрому має найнижчий опір зношуванню, а вищу зносотривкість - цинковий. Найвища зносотривкість властива покриву з твердого хрому та підкладці без покриву.

РЕЗЮМЕ. Исследовано трибологическое поведение трех видов электролитических покрывов: декоративного хрома, твердого хрома и цинка, сформированных на подкладке из стали С45. Использован трибометр при условиях возвратно-поступательного движения контртела. Обнаружено, что для всех покрывов значения стабилизированного коэффициента трения одинаковые, однако, существенно выше, чем для подкладки. Покрыв из декоративного хрома обладает наиболее низким сопротивлением изнашиванию, а цинковый наиболее износостойкий. Наивысшая износостойкость свойственна покрыву из твердого хрома и подкладке без покрыва.

1. Tribological properties of hard chromium coated 1010 mild steel under different sliding distances / A. El-Amoush, A. Abu-Rob, H. Edwan et al. // Solid State Sciences. - 2011. - 13. - P. 529-533.

2. Bozyazi E., Urgen M., and Cakir A. Comparison of reciprocating wear behavior of electrolytic hard chrome and arc-PVD CrN coatings // Wear. - 2004. - 256. - P. 832-839.

3. The correlation between the hardness and tribological behavior of electroplated chromium coatings sliding against ceramic and steel counterparts / Z. Zhixiang, W. Liping, C. Li, Z. Junyan // Surface \& Coatings Technology. - 2006. - 201. - P. 2282-2288.

4. Mechanical and tribological properties of electrolytic hard chrome and HVOF sprayed coatings / G. Bolelli, C. Valeria, L. Luca, R. Sara // Ibid. - 2006. - 200. - P. 2995-3009.

5. Panagopoulos C. N., Georgiou E. P., and Gavras A. G. Composite zinc-fly ash coating on mild steel // Ibid. - 2009. - 204. - P. 37-41.

6. Panagopoulos C. N., Georgarakis K. G., and Petroutzakou S. Sliding wear behavior of zinccobalt alloy electrodeposits // J. of Mater. Proces. Technol. - 2005. - 160. - P. 234-244.

7. Sliding wear behavior of zinc-iron alloy electrodeposits / C. N. Panagopoulos, P. E. Agathocleous, V. D. Papachristos, A. Michaelides // Surface \& Coatings Technology. - 2000. - 123. - P. 62-71.

8. Caprentier L. Caractérisation micromécanique de matériaux composites et anisotropes par indentation instrumentée. - Thesis, Ecole Centrale de Lyon, 1994. 